$$
\begin{aligned}
& (200) \\
& N 4334
\end{aligned}
$$

\author{
ONIIIED STATES \\ DEPARTMEATT OF THE TINTERIOR \\ GEOLOGICAL SURVEI \\ Ground Water Branch
}

\title{
SEISMIC CROSS SECTIONS ACROSS THE SPOKANE RIVER TALLEI AND THE HIIITARD TROUGH, IDAHO AND WASHINGTON
}
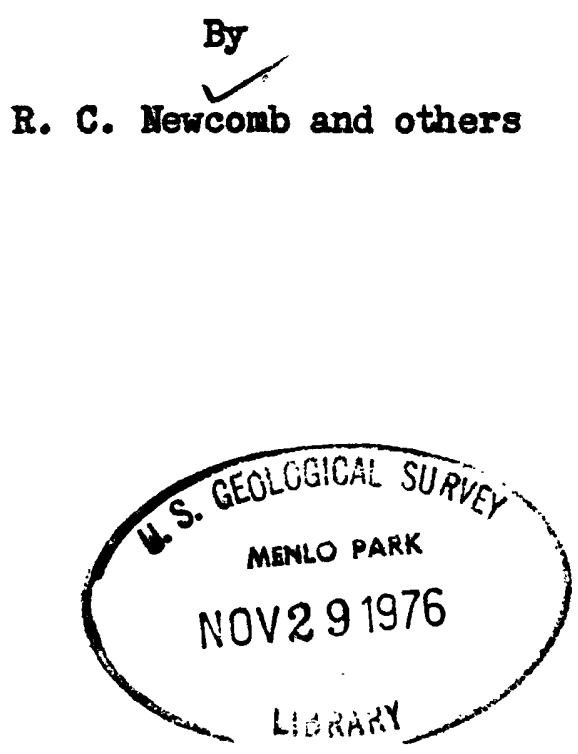

$$
\begin{aligned}
& \text { Portland, Oregon } \\
& \text { August } 1953
\end{aligned}
$$


Abstract .......................... 1

Introduction ......................... 3

General setting .................. 3

Purpose of study .................. 5

Organization of the work .............. 5

Selection of instrument ............. 5

Coordination of participating agencies ...... 5

Technical operation ............... 7

Location of sections ............. 7

Lajout and firing of shotlines ......... 7

Theory and operation of the seismograph ...... 8

General theory .............. 8

Operational process .......... 9

Factors adversely affecting operation...... 9

Presentation of results ........... 10

Selsmic profiles................. 11

General stratigraphic conditions observed . . . . . 11

Observations on the water table ........... 14

Conclusions . . . . . . . . . . . . . . 15

References cited ................ 16

\section{ILLUSTRATIUNS}

PLATE I

$\begin{aligned} & 2 \\ & 4 \\ & 4\end{aligned}-18$ 


\title{
SEISMIC CROSS SECTIONS ACROSS THE SPOKANE RIVER VATIEI AND \\ THE HTIIYADD TROOGH, TDAHO AND WASHIMGTON
}

By R. C. Newcomb and others

\begin{abstract}
Two seismic cross sections were run with a refraction seismograph near Spokane, Wash., in May and June 1951. One section trended northsouth across the Spokane River valley plain just east of the Idaho-Washington boundary; the other trended east-west across the strath just north of the Hillyard section of Spokane.

Each section secured data that permitted the compilation of a graphic cross section showing the position of (1) the water table, (2) the base of the glacial and glaciofluviatile deposits, and (3) the generalized base of the Iatah formation and associated deposits (which is the top of the consolidated bedrock).

The data confirm the inference of Pardee and Bryan that the granitic bedrock lies at an altitude of about 1,000 feet beneath the valley plain near the State boundary. The base (a heretofore unlocated feature) of the glacial outwash deposits, the main aquifer of the area, was determined as an weven plane at an altitude of 1,600 to 1,700 feet in the stateboundary district and at 1,700 feet in the Billyard Trough district.
\end{abstract}


INYRODUCTION

General Setting

The Spokane Valley and its northeasturard continuation, the Rathdrw Prairie, is a broad terraced valley 1loor, formed by the trains of glacial outwash that were deposited in the main ancestral drainage outlet of the Parcell Trench of the Rocky Mountains. There is physiographic contimuty of these valley terrece lands downslope from the terraces above the southern end of Iake Pend Orellle in Idaho to the Spokane Falls at Spokane. Dommvalley from Spokane Falls the same terrace level continues for many miles in the marginal terraces along the valley sides. The topography is shorm In a general way on the Spokane and Rathdrom quadrangle maps of the Geological Survey, and in more detail by the recent large-scale resurveys of those and adjacent quadrangles. Plate 1 shows the location of the seismic sezțions stadied.

The sides of the Spokane Valley are largely formed of resistant granitic and metamorphic rock. That rock also crops out from beneath the glacial outwash in the upper end of the valley near Ione Yountain and In the lower part of the valley near Irent. At Spokane the Spokane River falls 14 feet over basalt, Nors which supposedly belong to an intracawon lava epoch (Pardee and Bryan, 1925). Below the falls umch of the glactal outirash material has been removed from the valley. A tributary strath, known as the Hillyard Irough, enters from the north at Spokane in such a position as to indicate that it was once the min valley of the tributary Ittle Spokane River. 
A large body of ground water discharges an arerage of about 1,000 cuble feet of water per second (Fosdick, 1924) into the Spokane and Iittle Spokane Fivers in the reaches between Greenacres and the mouth of the Little Spokane River. It water table slopes gently southwestward from the upper Rathdrum Prairle section, where it is near the level of Lake Pend Oreille, to the Greenacres district, from hence to the falls it is at or near the level of the Fiver. Beneath the Hillyard Trough the water table slopes northward aw3y from the general level of the Spokane River and toward the spring orffices that occur along the south side of the Little Spokane River near Dartford (Newcomb, 1933).

Heretofore, it was not known to what depth the glacial outwash materials extended. Ifkewlse, in the deeper part of the valley, the nature of the rock beneath the glacial-outwash aquifer was unknown. Nlthough Pardee and Bryan (1925) had postalated an altitude of 1,050 feet for the granitic bedrock floor of the valley at the Idaho State boundary, on the basis of known present altitude of bedrock in the Purcell Trench, no actaal measurements had ever been obtained. Nlso mknown were (1) the depth at which the Latah formation and the Colmbia Biver basalt remain in the prebasalt grantific valley, and (2) the posstble water-bearing nature of those preglacial materials that filled the ancestral "granite" valley. 
Purpose of the Study

The primary objective of the seismic work was to locate the base of the glacial-outrash aquifer. Secondarily, it was desired to determine the type of materials anderlying the aquifer and to locate, where possible, the granitic bedrock of the ancestral valley. Charting of the water table and other features of the geology and ground water also was desired in order to help evaluate this exploratory process as a means for obtaining geohydrologic information.

The project was conceived as an effort to secure certain stratigraphic and hydrologic information that is vital to the correct derivation of the basic facts that govern the rater resources of the Spokane Valley. It was a part of the over-all Colnmbia River Basin investigation of the Geological Survey.

\section{Organization of the Work}

Selection of Instrwent

The Heiland 400 series, 4-channel seismograph instriment of the refraction type belonging to the U. S. Waterways Bxperiment Station was used.

\section{Coordination of Participating Agencies}

The offices of the Ground Water Branch of the Geological Swrves in the States of Washington, Idaho, and Oragon each furnished two men for most of the work. Selection of persomel to do the woxk for laying out the shotlines, Ior constructing and loading the shotholes, and for helping with the seismograph was made with a view toward achieving the madmam training in the technique of this type of exploration. Personnel working during a part 
of the project were Don Reis, Bruce Ifesch, and Maurice Jo Mnndorff from the Tacoma office, Don H. Hart and G. M. Hogenson of the Portland office, and James $R$. Jones of the Bolse office. Samuel W. West of the Bolse Jffice and R. C. Hewcomb of the Portland office worked throughont the project. The fleld work was done in $\mathrm{Key}$ and June 1951.

The J. S. Waterways Experiment Station of the J. S. Engineer Department furnished the seismograph instrument and tro operators, Peter Mrilinix and Joseph Jo OPNell. They supplied a report (O'Hell and kuitinix, 1951) on the work prior to the preparation of this report.

Iiaison with the J. S. Burean of Reclemation was made through Keith Anderson, regional dratnage engineer of the Rathdrum Prairte Irrigation Project. The Burean furnished a base map bearing a 2-foot contour interval for the State-Iine section.

The Washington Water Power Co. through William A. Hill and Walter E. Johnson gratuitously supplied a porren-driven pole-hole anger for a part of ane day, appreciably helping the project by digging sone 20 shotholes in the difficult boulder gravel of the State-line section. Fred 0. Jones of the Engineering Geology Branch of the Geological Survey made his Spolcane office arailable as headquarters for the woriding party.

The shothole data were coupreted and graphed by Don H. Bart and the resalts are shom on plates 4 to 18. Plates 2 and 3 were prepared by B. C. Hewconb. Iandowners and the county road anthorities of Spokane and Kootenal connties accorded permission for running the shotlines over their property. 
Technical Operations

Location of Sections

During the first two days, while araiting arrival of the instrament and the arrival of a supply of explosives, the tentative layout of the proposed selsmic section lines was reviewed and tro lines (one lying in a generally north-south direction across the valley a mile east of the Washington-Idaho boundary and one Ifing in an east-west direction across the Hillyard Trough north of Francis Street in Spokane) were chosen as best combining the required features.

\section{Iayout and Firing of Shotlines}

Shotlines were laid out along the line of each section as shown on plates 2 and 3. Each half of each shotline sas fired outward, four geophone locations at a time, from the origin or center point, except number 3 of the State-line section, a short line that was fired successively north to south. In effort was made to keep the digging crev ahead so that the firing and instrwment crew conld remain in continuous operation. That procedure worked out satisfactorily for most of the Hillyard Trough section, but difficulties in getting the holes dug and in getting satisfactory instrument records impeded progress on the State-line section. Shotholes having the heaviest charges were 8 to 10 feet deep on the Eillyard section and 5 to 7 leet deep on the State-line section.

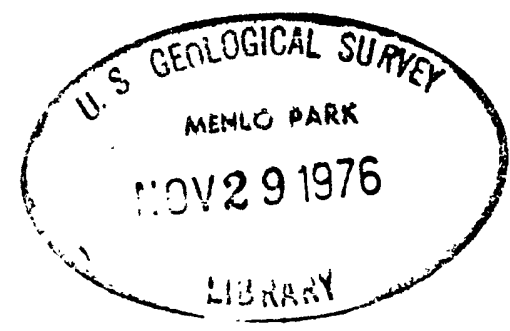


Blasting gelatin (60 percent) was used with standard electrical caps. Seismic-type gelatin was used on the State-line section and standard-type gelatin on the Hillyard Trough section. On the Hillyard Trough section the explosite loads rarled generally from $1 / 2$ pound in the holes at stations 0.90 (feet) to 14 or 16 pounds at the stations 14090 (feet). On the State-line section the loads were as high as 40 pounds in some experimental tests in the holes at greatest distance from the instrument.

Theory and Operation of the Selsmograph

General theory.- Refraction seismic methods of determining the subsurface structural relations of different lithologic units and stratigraphic horlzons are besed on SnelI's law. Detafled discussion of the physics of Snell's Iaw, with concerns the refraction of light waves passing through different media In wich light wares travel at different velocities, is bejond the scope of this report. It is important, however, to point to the practical applications of the law. Seismic exploration uses waves, which essentially are sound waves, whose speed of travel through earth materials depends upon the elastic properties and the density of the modinm.

In the practical application of selamic methods, the tern velocity is substituted for opeed, thus retaining the same magnitude but inclnding a drection of motion. The velocity of longltudinal selsmic waves is obtained by measuring the time betwean the intilation of the ware by an explosion and the retarn of impalses, which are recorded by geophones placed some distance from the point of explosion (shot point). 
An approximate image of each wave is reproduced on photographic paper by the selsmographic instrument. Arrival time and depth calculations give indications of changing media (rock units of different velocities and, hence, different densities and elastic properties) and the depths at which these changes occur. Correlation of this information with available surface and subsurface geologic data makes it possible to infer lithologic and stratigrapbic conditions and structural relations in areas beyond, or at depths beneath, those for which the direct observational data are araflable. When the shotlines are fired in one direction, as in this work, the relocitiesof-travel results are specifically known as "apparent" velocities of travel.

Operational process. - After each shot was fired the paper was developed and the elapsed time to the return impulse was recorded for each of the four geophones. Velocities of travel and depth of successive velocity-of-travel units were calculated as shown on plates 4 to 18. From the depth-units determined the stratigraphic cross sections were complled.

\section{Factors Adversely Affecting Operation}

The bouldery character of the glacial outwash deposits near the surface on the State-line section made the digging of shotholes extremely arduous and time conswing. Of the derices used there, the pole-hole power anger was the most satisfactory. On the State-line section, the great thickness of outiash msterials so absorbed the explosive impulse and so reakened the return impulse that some of the time readings, for shots at a considerable distance from the instrument, were determined with difficulty. 


\section{Presentation of Results}

Location and layout of the shotlines are shown on plates 2 and 3. The graphs giving velocity and depth zones encountered were plotted and forwarded with descriptive test by the 0 . S. Waterways Experiment Station to the Portland office of the Ground Water Branch of the Geological Survey. Those resalts were recalculated and checked and the cross sections were redrawn for this report.

A discussion of the nature of the recorded data is copied (with insertions) from the report of the $U_{0}$. S. Waterways Experiment Station as follows (OיPeil and Mollinix, 1951, p. 4-5):

Presentation of data

The results obtained from the test prafilles are shown by the inclosures and are briefly discussed herewith. Figares 1 and 2 [now plates 2 and 37 give profile Niews of the stratigraphic changes indicated from the readings and computation along the State-line and Hilljard Iine, respectively. IIme-distance. curves for the State-Iine profile are show on figares 5 through 11 [now plates 4 through 10$]$ and for the Hillyard profille on figures 12 through 19 [now plates 11 through 18]. Some very definite peculiarities are noted on the time-distance curves. The State-line plots indicate good recording until the longer shots when scattering is due to the fact that the energy was absorbed to a great extent by the bouldery surface layer. This difficulty could have been partially obviated by using shotholes of considerable depth. The arrival times of some secondary waves were plotted for line 2 South (figure 7) [now pl. 6, in order to help cancel the scattering and obtain more definite information on velocity changes. The plot of line 3 South (figure 9) Jnow pl. 97 presents this same generalized condition of 
seatterings. The scattering effect was not evidenced on the Hillyard profile, although a decided peculiarity exists on the curve of line I East (figure 12) [now pl. 11]. Almost identical time arrivals, geophone by geophone, from the 800-ft shot through that of 1490 ft indicate a boundary layer which refracted and reflected all oncoming energy. This phenomenon is interpreted as representing a steeply dipping boundary in the plane of the shotline. The curve of Iine I West (figure 13) [now pl. 12 ] presents erratic values so that, although the same velocity is present, there are two time-intercept values. The curves for line 3 East (figure 16) [now pl. 15 show a posstble velocity break around $1100 \mathrm{ft}$ shot distance. However, the computed depth when plotted on the profile, figure 2 [now pl. 3 ] does not agree with conditions on adjacent shotlines. Therefore, this point has not been considered in plotting the profile. The remaining Hillyard time-distance curves are generally straightforward in appearance."

\section{SEISIIC PROFTHES}

\section{General Stratigraphic Conditions Observed}

In general, four velocity-of-travel zones were detected. They were: (1) the soil and subsoil zone, (2) the "dry" glacial outwash above the water table, (3) the saturated glacial outwash and other unconsolidated materials(8), and (4) the underlying semiconsolidated or consolidated rock. The semiconsolidated or consolidated rock was further differentiated in some shotlines by the distinctive velocities of the granitic rock and the less distinctive velocities of the Latah formation and its (possible?) intercalated Igneous rocks. 
The apparent velocities of travel (in feet per second) weres

Hillyard section State-line section

(1) For the soil and subsoil zone of the glacial outwash

$\begin{array}{ll}900-1,300 & 1,230-1,640 \\ 2,150-2,700 & 3,330-4,500 \\ 5,000-7,000 & 5,660-7,500 \\ 7,400-9,600 & 8,870-12,800\end{array}$

(2) For the "dry" glacial outwash

(3) For the saturated glacial outwash

(4) For the Latah formation and the Iatah with intercalated igneous rocks(8)

(5) For granitic bedrock

$13,200-20,000$

$13,200-20,000$

The time intercepts and calculations on which those velocity-of-travel zones are based are shown on plates 4 to 18.

The velocities obtained for the Latah formation in the State-line profile are so high that it seems reasonable to assume that the basalt sills and dikes like those present in the Latah formation in the Latah Creek Ficinity (Pardee and Bryan, 1925) and those visible in the highway cuts fast southeast of Coeur d'Nlene, Idaho, are present also beneath the State-line area.

The base of the offcial outwash material (or of other unconsolidated material, if any, overlying the Latah formition) is shown as an unculating contact ranging in altitude from 1,600 to 1,750 feet in the Stato-1ine section and as a more regular contact at 1,700 feet in the Hillyard Irough section. 
If in preglacial time, as postulated by Pardee and Bryan (1925), the Latah formation and basalt were eroded from the valley to an altitude of 1,460 feet (altitude of base of "valley flows" in Davenport Hotel well) before the intracanyon flows filled it to an altitude of 2,200 to 2,400 feet, one would expect to find in these sections some remnants of a semiconsolIdated lake deposit 1 fing in the 1,460-2,200-1oot interval. If present, such beds must have a velocity of saismic travel that is similar to that of the Latah formation and are included by the writers in the zone of . the Latah formation proper.

The apparent position of the base of the glacial outwash at altitudes of 1,600 to 1,750 feet in the State-line section and of 1,700 feet in the Hillyard Trough section, or roughly 100 to 200 feet below the altitude of the bedrock crest of the present falls at Spokane (about 1,860 feet) is significant. It seems to augment the postulation (Newcomb, 1933) that an older preglacial Spokane-River-Falls channel (probably cut to an altitude as Iow as $1,600^{\text {t }}$ feet) lies buried by the glacial outwash somewhere between the basalt knobs that crop out just north of the present Spokane Palls and the south slope of the Fivemile Prairie ontlier.

It seems possible that the basalt at the Spokane Falls is a sill or dike-and-sill complex, on which the normal dowmard cutting of the Spokane Biver was base leveled even in preglacial times. If so, the strate of the Iatah formation must remain evergwhere in the valley areas belor the 1,860:-foot altitude of the present channel or, if the older, deeper north-central channel mentioned above exists, at least everywhere below the 1,600-to 1,750-foot altitude of that channel: That such a situation Weigle (1952) Ilsts some deeper glacial materlals in the logs of some wells at the aluminum plant near Kead, 2 miles north of the Hillyard seismic section. 
exists is suggested by the lack, in the zone normally occupied by the Latah formation, of any seismic velocities lower than those characteristic of that formation.

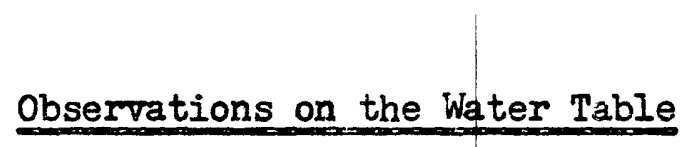

The altitude of the water table, as obtained by these seismic sections, may vary as much as 12 feet from the true altitude existing at the time. Iise altitude of the water table, by hand tape measurement of the Peter Beck well, 800 feet east of shotline I S of the State-line section, was 1,995.6 feet on July 6, 1950 (Fader, 1952), and by interpolation of urpublished hydrographs was 1;991.8 feet on May 24, 1951. The seismic profile places it at 1,980 feet on May 24, 1951. The altitude of the water table in a new well 200 feet west of shotline $4 \mathrm{~S}$ in April 1952 was reported by the owner as 1,983 feet (132 feet below land surface). Interpolated from other wells the altitude on June 8, 1951, is estimated as $1,988^{\circ}$ feet. The altitude of the water table as determined there by the seismic work on June 8,1951 , was 1,983 feet. 


\section{CONCLUSIONS}

The general bellef that the granitic bedrock valley profile extends to an altitude of 1,000 feet or so beneath the State-line district seems borme out by the velocities of travel found in the strata beneath that seismic section line.

The base of the glacial outwash deposits, the main aquifer of the valley, is an uneven plane at an altitude of 1,600 to 1,750 feet in the State-line district and at 1,700 feet in the Hillyard Trough district.

The water table was recorded with an approximate error of 5 to 12 feet, or a margin of error that may be less than the annual fluctuation of the water table.

Recommendations on the future technique of such surveys include the circumvention of the difficulties encountered in digging shotholes in the bouldery gravel of the State-line section by: (I) use of selsmic instrument that has 6 or more channels in order to decrease the number of shotholes necessary, and (2) the construction by churn drill, to a depth of 25 feet or so, of the shotholes beyond the $6 \& 40$ station of each shotline. 
REHEREMTEES CITEN

Fader, S. W., 1951, Water levels in rells and lakes in Rathdrum Pratrie and contigaous areas, Bonner and Kootenal counties, northern Idaho: J. S. Geol. Surrey open-file report.

Fosdick, E. R., 1924, Ground water of the Spokane Valley: a private report of Washington Water Power Co.

Newcomb, R. G., 1933, Onderground sater of the upper Spokane River valley: Washington State Coli. bachelot's thesis.

O'NeIl, Joseph J., and Mullinix, Peter, I95I, Seiswie survey of the Spakane Biver valley:", U. S. Eng. Dept., Waterilays Exper. Sth., typewritton report.

Pardee, J. T., and Bryan, Kirk, 1925, Geolosy of the Iatah formation in relation to the lavas of Columbia Platean near Spokane, Wash.: J. S. Gool. Surrey Prof. Paper Ilô-A.

Weigle, James E., 1952, Factual data on the gropnd-water resources of the Spokane valley, Wash.: U. S. Geol. Survey open-flle report. 